\title{
Factors Affecting The Jordanian Purchasing Behavior Of Housing Apartments: An Empirical Study In Irbid City
}

\author{
Dr. Ibrahim Mohammed Khrais \\ Associate Professor of Economy, Zarqa University, Jordan
}

doi: 10.19044/esj.2016.v12n7p446 URL:http://dx.doi.org/10.19044/esj.2016.v12n7p446

\begin{abstract}
The aim of this study is to show the extent of the impact of factors that affect the purchasing behavior of housing apartments per capita in Irbid city. It discusses the most influential factors in the purchasing decision for housing issues. These factors are independent factors: structural, geographical, environmental, and economical. Data was collected via questionnaires which were distributed to a sample of 150 individuals who are owners of apartments in Irbid city (Northern Jordan). The study showed different results and the various factors (structural, geographical, environmental, economical, and demographic) which have a significant impact on the purchasing decision of housing apartments in Irbid city. It is evident that these factors in full manner and the structural factors (construction area, land area, finishing, age of the building, and the outer shape) have an effect on the decision making process of the respective apartments.
\end{abstract}

Keywords: Purchasing Behavior, Housing Apartments, Jordan

\section{Introduction}

In Jordanian community, the housing sector plays a significant role among other things that worries Jordanian people. Nowadays, we can see that housing area in Jordan tends to decline, as the average housing space decreased from $118 \mathrm{~m}$ (1999) to $115 \mathrm{~m}$ (2007). The per capita household space rate is $20 \mathrm{~m}$, while the global average is $138 \mathrm{~m}$.

The housing sector in Jordan is characterized as a private sector activity and primarily as an individual activity. However, the public sector plays an important role for some of the employees' citizens' categories. This role supervises the sector and the organizer of the General Organization for Housing and Urban Development. Subsequently, it also contributes to achieving the prosperity of many entities such as the Military Housing 
Foundation, which was founded in 1969, the housing cooperative societies that are scattered in various governorates of the Kingdom, and other housing funds of the ministries and government institutions. This is in addition to some non-governmental organizations and lending institutions. Furthermore, the private sector contributes clearly to providing housing for some segments of the society, especially those of the high and middle income.

\section{Objectives of the Study}

This study aims to achieve the following objectives:

1. To determine the influence of independent factors (structural, geographical, environmental, and economical) on the purchasing decision of housing apartments in Irbid city.

2. To determine whether the effect of independent factors in the purchasing decision varies, depending on the characteristics of the study population (of the category of consumers) in terms of the income level, educational level, family size, and occupation.

3. To determine which independent factors are the most influential on individuals of the study population when making a decision to purchasing housing property.

The Model of the Study Based on the hypotheses of the study, its problem, and with reference to previous studies, the researcher put on the proposed model as shown below:

\section{Variables/Model of the study}

\section{Independent variables}

- Geographical factors

- Environmental factors

- Economic factors

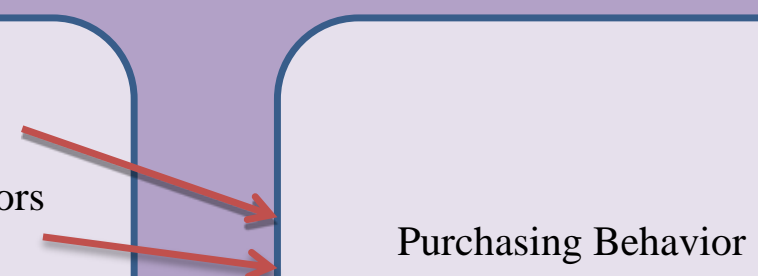


In this study, we have two groups of related variables which are: the dependent variables and the independent variables. Thus, they are described as follows:

\section{Dependent Variable}

Purchasing Behavior: Purchasing behavior is represented by a range of activities that cannot be watched constantly. However, it is only expressed when making a purchasing decision, as well as the actions that precede. The virtual and final behavior of the individual, are interacting and overlapping and may be long-lasting. Other times, virtual behavior would be for a short period and then ends and disappears. This means that the purchasing decision process is the one which identifies the behavior. Therefore, it is the result of the decision-making procedures that drive the individual to search for a product or service and then find themselves in front of many products or services to choose from (Alsumedei \& Rudeina 2001).

\section{Independent Variables}

(A) Structural Factors: The intended structural factors in this study include the construction area, land area, the quality of construction, the shape of the building from outside, and the impact of these factors on the purchasing decision.

(B) Geographical Factors (location): The geographical factors in this study refer to the elements related to the geographical location of the building whether it is a mountain, plain, or a valley site. However, it also refers to whether the site is quiet and classy, or popular and crowded, and the impact of these things on the purchasing decision.

(C) Environmental Factors: The study examined environmental factors related to inconvenience and chaos in the region, distance or proximity to the main street, or the proximity and distance of the important vital facilities. However, it also considers the impact on the purchasing decision of the apartment.

(D) Economic Factors: These are factors that relate to the price of the property, the level of the cost of living, and its impact on the individual owner of the apartment purchasing decision.

\section{Literature Review}

There are many studies that mention the issue of apartments' purchasing behavior. These studies work to recognize the determinants thereof and the purchasing decision-making process as well. Given the complexity and large number of these studies and their relationship with consumer behavior, which have varied fields and objectives, the researcher selected various studies of concern which relates to this paper. They include: 
- Abu Aisha (1993) tackled the impact of marketing and housing policies on the degree of satisfaction among the beneficiaries of urban development projects in Amman. Her study is aimed to clarify the housing reality in Jordan through urban development projects, public complexes in Jordan and analysis of the marketing mix for complexes elements, and the development of appropriate solutions to the problem of housing in Jordan. Accordingly, this study shows that there is a statistically significant relationship between the housing characteristics and type, as well as the satisfaction towards housing issue. Moreover, this study also discussed the statistical significant relation between price satisfaction and the reimbursed monthly installments imposed on beneficiary. At the same time, the results show that urban development projects are not well promoted. Thus, selling of the units is under normal margin.

- Rawabdeh (1988) discusses supply and demand issue, and further factors influencing the demand. The results shown are as follows:

A. Unavailability of comprehensive and clear housing policy in terms of the objectives at the national level.

B. The problem of housing still exists. Thus, this is due to the fact that existing financial facilities do not fit most of the people in bearing the burden of paying the prices of houses.

C. The demand on houses is directly affected by the capita income, and is inversely affected by rents.

- Levy \& lee (2004) study, has dealt with the different roles of family members in making the purchasing decision in New Zealand. However, it also measures the impact of family members decisions through personal interviews in order to collect the data from the viewpoint of nine Real Estate brokers. Hence, it was stated that the decision-making process depends on getting the greatest benefit. The study also figures out the factors that impact the purchasing-decision which include differences in the classes and the culture.

According to the study that distinguishes between the traditional and realistic types of decision-making, the realistic type assumes that the purchasing decision of housing is affected by the interest of the purchasing decision makers. Consequently, the researcher obtained the difference between the expectation of the purchasing decision maker and the actual results of the decision-making process. Accordingly, the researcher could identify the difference between the traditional and the realistic 
type. Therefore, the traditional type helps in discovering the application of some behavioral habits. At the same time, it also has the beliefs that the purchasing decision is done economically and financially. On the other hand, the realistic type helps in understanding the person's purchasing decision-making process.

- Littlefield \& cook (2000) studied the measure of the extents of the Internet's published posts. A random sample of 1506 people was selected. 499 valid questionnaires were retrieved for the analysis. Thus, it was observed that $40 \%$ of the study sample used the Internet to get the necessary information to purchase real estates. Such use is influenced very easily by the Internet, age, and the level of awareness of the importance of using Internet in the purchase of real estate.

- Livett (2006) discussed the pensioners purchasing behavior in Britain, and the process of making the decision of purchasing the housing for the sake of looking for such a type of housing. Here, the sample was taken from 200 pensioners from Britain, The results of this study showed that the majority of purchasers are more interested to pay and own the housing plan. However, this plan comes to the surface because those pensioners are either unable to manage their current place of living or they want to live close to their friends.

- Aldmour (2004) tackles the impact of the marketing mix elements in the purchasing decision of housing properties in Jordan. In addition, Aldmour determined the most influential element of this decision, the effect of various characteristics of the study population, and the most important sources of information for the purchaser when making the purchasing decision. The data was collected by distributing the questionnaire among a sample of 155 members; i.e. owners of apartments in West Amman area. Hence, the study shows the following results:

A. There is an impact of the four element of the marketing model on the purchasing decision of housing in the Jordanian market.

B. There is a difference in the extent of impact of housing properties marketing mix on the purchasing decision depending on the characteristics of the study sample.

C. It adopted the Jordanian individual who is the purchasing decision maker. In addition, he takes into consideration the opinion of his family members to be an essential source of information in the first place. Thus, this is followed by architects, and finally his friends' opinion. 
- Haddad \& Judah (2011) discussed the main influencing reasons on the purchasing decision of housing apartments in Amman city. The study sample is consisted of 120 people who have purchased apartments in different areas in Amman city. The questionnaire was analyzed by using ANOVA method. Accordingly, the study shows the following results:

A. The members purchasing decision of the study sample is influenced by many considerations: economical, marketing, geographical, and social consideration. The foregoing would be considered before making the purchasing decision.

B. The impact of these factors varies from one person to another according to the sex and age of the purchasing decision maker.

C. There is a statistically significant relationship regarding the social status and educational level on purchasing decision making.

\section{Methodology of the Study}

\section{- $\quad$ The Study Population and Sample}

The respective questionnaires were distributed in October 2014, among 150 owners of apartments in Irbid city. Thus, this was specifically distributed to those who have purchased their apartments during the last ten years. The total persons who responded to the questionnaire were 109, and were rated at $72 \%$. While 41 questionnaire sheets were excluded from the study, some indicated no answer. On the other hand, others contain wrongful answers. Subsequently, 109 questionnaires were answered out of 150 and were subject to analysis; i.e. the proportion of recovered and approved questionnaires for the purposes of statistical analysis is $72 \%$.

\section{- Data Collection Tools}

Both secondary and primary data were used by the researcher in this study. Books, magazines, and periodicals were used to get relevant secondary topics. The preliminary data were collected through a questionnaire, prepared for this purpose, and were distributed to the study sample.

\section{- $\quad$ Analyzing the Results of the Field Study}

The table below processes and analyzes the data from the recovered questionnaires. However, this occurs by converting the metadata to quantitative data through encoding, filling the answers manually, discharging them from the prepared tables for this purpose, and entering them into the computer using the statistical analysis software (SPSS).

\section{Hypotheses of the Study}

In answering the study questions, the hypothesis has been formulated to the null hypothesis as follows: 


\begin{tabular}{|c|l|}
\hline \multicolumn{1}{|c|}{$\mathbf{H}_{\mathbf{0 1}}$} & $\begin{array}{l}\text { There is no statistical significant relation among various factors on } \\
\text { the purchasing decision of housing apartments in Irbid city. }\end{array}$ \\
\hline $\begin{array}{c}\text { This hypothesis } \\
\text { influencing factors on the purchasing decision of housing apartments in Irbid city. }\end{array}$ \\
\hline $\mathbf{H}_{\mathbf{0} \text { 1 }}$ & $\begin{array}{l}\text { There is no statistical significant relation among structural factors on the } \\
\text { purchasing decision of housing apartments in Irbid city. }\end{array}$ \\
\hline $\mathbf{H}_{\mathbf{0} \text { 1 }}$ & $\begin{array}{l}\text { There is no statistical significant relation among geographical factors on } \\
\text { the purchasing decision of housing apartments in Irbid city. }\end{array}$ \\
\hline $\mathbf{H}_{\mathbf{0} \text { 1 }}$ & $\begin{array}{l}\text { There is no statistical significant relation among environmental factors } \\
\text { on the purchasing decision of housing apartments in Irbid city. }\end{array}$ \\
\hline $\mathbf{H}_{\mathbf{0} \text { 1 } \mathbf{D}}$ & $\begin{array}{l}\text { There is no statistical significant relation among economic factors on the } \\
\text { purchasing decision of housing apartments in Irbid city. }\end{array}$ \\
\hline
\end{tabular}

\section{Hypothesis Testing}

A descriptive method has been used to prove or deny the hypotheses of the study. Thus, the questionnaire has been divided into five sections. Each section deals with the specific part of the hypotheses of the study. This questionnaire was distributed to 150 owners of apartments in Irbid city. Subsequently, 109 questionnaires were recovered after the researcher distributed it to those owners. The questionnaire has been reviewed and evaluated by specialized academics in statistics, finance, and economic sciences.

Consequently, weights were given to the sample respondent's answers as shown in Table (1) (Five-level Likert scale) below:

Table (1). Five-level Likert scale

\begin{tabular}{|c|c|c|c|c|c|}
\hline Answer & Strongly agree & Agree & Neutral & Disagree & $\begin{array}{c}\text { Strongly } \\
\text { disagree }\end{array}$ \\
\hline Weight & 5 & 4 & 3 & 2 & $\mathbf{1}$ \\
\hline
\end{tabular}

The Reliability test has been concluded to show that the result was statistically acceptable. Furthermore, the alpha coefficient accounted for $87 \%$. Therefore, this indicates the possibility of relying on the resulted information through these questionnaires.

\section{Main Hypothesis $\mathbf{H}_{0}$}

There is no statistical significant relation for the various factors on the purchasing decision of housing apartments in Irbid city, especially when these factors are taken together.

This hypothesis has been tested through the analysis of all the questionnaire's fifteen questions. Here, the average of the sample respondent's answers was 78.5, which is lower than the overall average for all questions (23.5). Nevertheless, this difference has a statistical significant at the confidence level 95\%. Thus, this means rejecting the null hypothesis and accepting the alternative hypothesis. This states that the various factors 
have an effect on the purchasing decision of housing apartments in Irbid city, especially when these factors are combined.

\section{One-Sample Statistics}

\begin{tabular}{||c|c|c|c|c||}
\hline \hline Std. Error Mean & Std. Deviation & Mean & $\mathrm{N}$ & \\
\hline 1.573 & 16.423 & 78.50 & 109 & $\mathrm{H} 1$ \\
\hline
\end{tabular}

\section{One-Sample Test}

\begin{tabular}{||c|c|c|c|c|c||}
\hline & & & & & $\begin{array}{c}\text { Test Value } \\
=102\end{array}$ \\
\hline & $95 \%$ Confidence Interval of the Difference & $\begin{array}{c}\text { Mean } \\
\text { Difference }\end{array}$ & $\begin{array}{c}\text { Sig. } \\
(2- \\
\text { tailed })\end{array}$ & df & $\mathrm{T}$ \\
\hline Upper & Lower & & & & \\
\hline-20.39 & -26.62 & -23.50 & .000 & 108 & -14.942 \\
\hline
\end{tabular}

\section{One-Sample Statistics}

\begin{tabular}{|c|c|c|c|c|}
\hline Std. Error Mean & Std. Deviation & Mean & $\mathrm{N}$ & \\
\hline .87249 & 28.52668 & 144.3648 & 109 & sat \\
\hline
\end{tabular}

\section{One-Sample Test}

\begin{tabular}{|c|c|c|c|c|c|c|}
\hline \multicolumn{6}{|c|}{ Test Value $=117$} & \\
\hline \multicolumn{2}{|c|}{$\begin{array}{l}\text { 95\% Confidence } \\
\text { Interval of the } \\
\text { Difference }\end{array}$} & \multirow[t]{2}{*}{$\begin{array}{c}\text { Mean } \\
\text { Difference }\end{array}$} & \multirow[t]{2}{*}{$\begin{array}{l}\text { Sig. (2- } \\
\text { tailed) }\end{array}$} & \multirow[t]{2}{*}{$\mathrm{df}$} & \multirow[t]{2}{*}{$\mathrm{T}$} & \\
\hline Upper & Lower & & & & & \\
\hline 29.0768 & 25.6528 & 27.36483 & .000 & 1068 & 31.364 & sat \\
\hline
\end{tabular}

\section{Sub-first Hypothesis}

$\mathbf{H}_{\mathbf{0}} \mathbf{1}$ : : There is no statistical significant relation for structural factors on the purchasing decision of housing apartments in Irbid city.

This hypothesis was tested through the first five questions. However, the overall arithmetic mean and standard deviation is given as follows:

\begin{tabular}{|c|c|c|}
\hline Questions & $\begin{array}{c}\text { Arithmetical } \\
\text { mean }\end{array}$ & $\begin{array}{l}\text { Standard } \\
\text { deviation }\end{array}$ \\
\hline Structural factors & \multirow{6}{*}{9.10} & \multirow{6}{*}{2.835} \\
\hline 1 .Construction area did not influence my decision in purchasing apartments. & & \\
\hline 2- Land area did not influence my decision in purchasing apartments. & & \\
\hline 3- The apartment in final finishing did not influence my purchasing decision. & & \\
\hline 4- The age of the building did not influence my purchasing decision. & & \\
\hline 5- The building's outer shape did not influence my purchasing decision. & & \\
\hline
\end{tabular}


One-Sample Statistics

\begin{tabular}{||c|c|c|c|c||}
\hline $\begin{array}{c}\text { Std. Error } \\
\text { Mean }\end{array}$ & $\begin{array}{c}\text { Std. } \\
\text { Deviation }\end{array}$ & Mean & $\mathrm{N}$ & \\
\hline .272 & 2.835 & 9.10 & 109 & H1A \\
\hline
\end{tabular}

\section{One-Sample Test}

\begin{tabular}{||c|c|c|c|c|c|c||}
\hline & & & & $\begin{array}{c}\text { Test } \\
\text { Value } \\
=12\end{array}$ \\
\hline & $\begin{array}{c}\text { 95\% Confidence Interval of } \\
\text { the Difference }\end{array}$ & Mean Difference & $\begin{array}{c}\text { Sig. (2- } \\
\text { tailed) }\end{array}$ & Df & $\mathrm{t}$ & \\
\hline Upper & Lower & & & & & \\
\hline-2.36 & -3.44 & -2.90 & .000 & 108 & $\begin{array}{c}- \\
10.677\end{array}$ & H1A \\
\hline
\end{tabular}

The average of the sample respondent's answers is 9.1, which is less than the overall average for all the questions (2.9). This difference has a statistical significant at the confidence level 95\%. Thus, this means rejecting the null hypothesis and accepting the alternative hypothesis. This states that the structural factors have an effect on the purchasing decision of housing apartments in Irbid city.

\section{Sub-second Hypothesis}

$\mathbf{H}_{\mathbf{0}} \mathbf{\text { в}}$ : There is no statistical significant relation among geographical factors on the purchasing decision of housing apartments in Irbid city.

This hypothesis was tested through five questions. However, the overall arithmetic mean and standard deviation is given as follows:

\begin{tabular}{|c|c|c|}
\hline Questions & $\begin{array}{c}\text { Arithmetical } \\
\text { mean }\end{array}$ & $\begin{array}{l}\text { Standard } \\
\text { deviation }\end{array}$ \\
\hline Geographical factors (site) & \multirow{6}{*}{17.17} & \multirow{6}{*}{4.292} \\
\hline $\begin{array}{l}\text { 6. Mountainous site for construction area did not } \\
\text { influence the purchasing decision. }\end{array}$ & & \\
\hline $\begin{array}{l}\text { 7. Plain site for construction area did not influence } \\
\text { the purchasing decision. }\end{array}$ & & \\
\hline $\begin{array}{l}\text { 8. Low-site of the construction area did not influence } \\
\text { the purchasing decision. }\end{array}$ & & \\
\hline $\begin{array}{l}\text { 9. Quiet site for the area of building did not influence } \\
\text { the purchasing decision. }\end{array}$ & & \\
\hline $\begin{array}{l}\text { 10. Local and densely site of the construction area did } \\
\text { not influence the purchasing decision. }\end{array}$ & & \\
\hline
\end{tabular}


One-Sample Statistics

\begin{tabular}{|l|c|c|c|c|c|}
\hline & Std. Error Mean & Std. Deviation & Mean & $\mathrm{N}$ & \\
\hline & .411 & 4.292 & 17.17 & 109 & H1B \\
\hline
\end{tabular}

\section{One-Sample Test}

\begin{tabular}{||c|c|c|c|c|c|c||}
\hline & & & & $\begin{array}{c}\text { Test Value } \\
=24\end{array}$ & \\
\hline & $\begin{array}{c}95 \% \text { Confidence Interval of the } \\
\text { Difference }\end{array}$ & $\begin{array}{c}\text { Mean } \\
\text { Difference }\end{array}$ & $\begin{array}{c}\text { Sig. (2- } \\
\text { tailed) }\end{array}$ & $\mathrm{df}$ & $\mathrm{t}$ & \\
\hline Upper & Lower & & & & & \\
\hline-6.01 & -7.64 & -6.83 & .000 & 108 & -16.603 & H1B \\
\hline
\end{tabular}

This hypothesis has been tested through the analysis of all the questionnaire's fifteen questions where the sample respondent's answers average was 17.7. Thus, this is lower than the overall average for all questions (6.83). The alternative hypothesis, states that the statistically significant geographical factors, have an effect on the purchasing decision of housing apartments in Irbid city.

\section{Sub-third Hypothesis}

$\mathbf{H}_{\mathbf{0 1}} \mathrm{c}$ : There is no statistical significant relation among environmental factors on the purchasing decision of housing apartments in Irbid city.

This hypothesis was tested through three questions. However, the overall arithmetic mean and standard deviation is given as follows:

\begin{tabular}{|c|c|c|}
\hline Questions & $\begin{array}{c}\text { Arithmetical } \\
\text { mean }\end{array}$ & $\begin{array}{l}\text { Standard } \\
\text { deviation }\end{array}$ \\
\hline Environmental factors (site) & \multirow{4}{*}{18.00} & \multirow{4}{*}{3.639} \\
\hline $\begin{array}{l}\text { 11. The noise and chaos in the construction area did not } \\
\text { influence the purchasing decision in the apartment that I } \\
\text { own. }\end{array}$ & & \\
\hline $\begin{array}{l}\text { 12. The location as to main highway did not the } \\
\text { purchasing decision in the apartment that I own. }\end{array}$ & & \\
\hline $\begin{array}{l}\text { 13. Public services availability did not influence the } \\
\text { purchasing decision in the apartment that I own. }\end{array}$ & & \\
\hline
\end{tabular}

\section{One-Sample Statistics}

\begin{tabular}{|c|c|c|c|c|c|}
\hline & $\begin{array}{c}\text { Std. Error } \\
\text { Mean }\end{array}$ & Std. Deviation & Mean & $\mathrm{N}$ & \\
\hline & .349 & 3.639 & 18.00 & 109 & H1C \\
\hline
\end{tabular}


One-Sample Test

\begin{tabular}{|c|c|c|c|c|c|c||}
\hline & & & & $\begin{array}{c}\text { Test Value } \\
=24\end{array}$ & \\
\hline & $\begin{array}{c}95 \% \\
\text { Confidence } \\
\text { Interval of the } \\
\text { Difference }\end{array}$ & $\begin{array}{c}\text { Mean } \\
\text { Difference }\end{array}$ & $\begin{array}{c}\text { Sig. (2- } \\
\text { tailed) }\end{array}$ & df & $\mathrm{T}$ & \\
\hline Upper & Lower & & & & & \\
\hline-5.31 & -6.69 & -6.00 & .000 & 108 & -17.215 & H1C \\
\hline
\end{tabular}

The sample respondent's answers accounted for 18, which is less than the overall average for all the questions (6). This difference has a statistical significant at the confidence level 95\%, which means rejecting the null hypothesis and accepting the alternative hypothesis. This states that the environmental factors have an effect on the purchasing decision of housing apartments in Irbid city.

\section{Sub-fourth Hypothesis}

$\mathbf{H}_{\mathbf{0 1}}$ D: There is no statistical significant relation among economic factors on the purchasing decision of housing apartments in Irbid city.

This hypothesis was tested through two questions. However, the overall arithmetic mean and standard deviation is given as follows:

\begin{tabular}{||c|c|c|}
\hline \multicolumn{1}{|c|}{ Questions } & $\begin{array}{c}\text { Arithmetical } \\
\text { mean }\end{array}$ & $\begin{array}{c}\text { Standard } \\
\text { deviation }\end{array}$ \\
\cline { 1 - 2 } Economic factors (site) & \multirow{2}{*}{15.96} & \multirow{2}{*}{4.927} \\
$\begin{array}{l}\text { 14. The price of the property did not influence the } \\
\text { purchasing decision in the apartment that I own. }\end{array}$ & \\
\cline { 1 - 2 } $\begin{array}{l}\text { 15. The financial capability did not influence the } \\
\text { purchasing decision in the apartment that I own. }\end{array}$ & & \\
\hline
\end{tabular}

\section{One-Sample Statistics}

\begin{tabular}{||c|c|c|c|c||}
\hline Std. Error Mean & Std. Deviation & Mean & $\mathrm{N}$ & \\
\hline .472 & 4.927 & 15.96 & 109 & H1D \\
\hline & & & & \\
\hline
\end{tabular}

\section{One-Sample Test}

\begin{tabular}{|c|c|c|c|c|c|c|}
\hline & & & & & Test Value = 24 & \\
\hline & $\begin{array}{c}\text { 95\% Confidence } \\
\text { Interval of the } \\
\text { Difference }\end{array}$ & $\begin{array}{c}\text { Mean } \\
\text { Difference }\end{array}$ & $\begin{array}{c}\text { Sig. (2- } \\
\text { tailed) }\end{array}$ & $\mathrm{df}$ & $\mathrm{t}$ & \\
\hline Upper & Lower & & & & & \\
\hline-7.10 & -8.97 & -8.04 & .000 & 108 & -17.029 & $\mathrm{H} 1 \mathrm{D}$ \\
\hline
\end{tabular}


The average of the sample respondent's answers is 15.96, which is less than the overall average for all the questions (8.04). This difference has a statistical significant at the confidence level 95\%, which means rejecting the null hypothesis and accepting the alternative hypothesis. This states that the economic factors have an effect on the purchasing decision of housing apartments in Irbid city.

\section{Results}

1. The various factors (structural, geographical, environmental, economical, and demographical) do impact the purchasing decision of housing apartments in Irbid city if we consider these factors in full manner.

2. The structural factors (construction area, land area, finishing, age of the building, and the outer shape) are evident to have its effect on respective apartments' decision-making in the city of Irbid.

3. The geographical factors (mountainous, plain, low, and quiet location) have its influence on the individual when the individual is selecting an apartment.

4. The environmental factors (noise, location as to main highway, public services availability) have a major impact on decision-making.

5. The economic factors (price $\&$ financial capacity) have a notable effect on decision-making as to purchasing apartments in Irbid city.

\section{Recommendations}

1. There are benefits acquired from the experiences and opinions of apartment owners when making a purchasing decision, since they form an important database for the next purchasers during their first time.

2. Encourage the role of real estate companies through the credibility in the presentation of apartments, provide a clear picture to purchasers, and impose after sale services if possible. Structure maintenance is needed once at a certain period of time after sale.

3. Taking into consideration the importance of the price factor and link it to the want to purchase housing apartments, and considering it as the most important factor.

4. Provide favorable conditions by the owners of real estate companies for the next purchasers. Thus, this provides facilities for payments or other financial activity.

\section{Funding}

This research is funded by the Deanship of Scientific Research, Zarqa University. 


\section{References:}

Abu Baker \& Mustafa (2004). Marketing Management in Modern institutions, Dar aljamea, Egypt.

Aldmour \& Hani (2004). Services Marketing, Wael for publishing and distribution, Amman.

Alrawabdeh \& Abdullah (1998). Housing Marketing in Jordan, Unpublished Master Thesis, University of Jordan, Amman, Jordan.

Alsamedei, Mahmoud \& Rudeina (2001). Consumer behavior Analytical and Quantitative Introduction, Almanhej for publishing and distribution, Amman. Alsahen \& Mohamad (2002). Reading in Marketing Management, Dar aljamea, Iskandria, Egypt.

Alserfi \& Mohamad (2003), Lead Department, Alsafaa for publishing and distribution, Amman- Jordan.

Alshala (2005), Alrai Newspaper, Vol 12624, p. 22.

Ashour, Naeem \& Rasheed (2000). Marketing Principles, Alyazouri scientific for publishing and distribution, Amman- Jordan.

Bin Yaqoub Altaher (2003). Consumer Behavior role in determine Marketing Policies, Doctoral Thesis, Farahat Abbas University, Satef. Hua Kiefer, M.A.,2007.Essays on Applied spatial econometrics and housing economics .Ph.D. Thesis OHIO State University ,USA.

Kotler \& keller (2006). Marketing Management Prentice-hall, NY, $12^{\text {th }}$ Edition.

Levy \& Lee (2004). The Influence of Family Member on Housing Purchase Decision. Journal of Property Investment and Finance, Emerald Group Publishing Ltd.

Lenzen \& Treloar (2006). Embodied energy in building: Wood Versus Conecentrate - reply to Borjesson and Gustavssn. Energy Policy , 30:249255.

Livwtte \& Martin (2006). A Marketing Perspective of Private Sector Retirement Of Housing and the Effectiveness of the Buer Behaviors of its Purchasers, Property Management,24(4):383-369.

Lovelock \& Wirtz (2004). Service Marketing, $3^{\text {rd }}$ Edition, PRENTICE-Hall, International Edition, N.y.

Maala, Naji \& Raef (2005). Marketing Principles, Wael for publishing and distribution, Amman.

Mithraratne \& Vale (2004). Life cycle analysis model for new Zealand houses, Buill , Environ.,39:483-462.

Obeidat \& Mohamad (2006). Consumer Behavior, Wael for publishing and distribution, Amman.

Streiner (2006). Sample size in clinical research: When is enough? J.Pers. Assess.,87(3):259-260. 